\title{
TUBERCULOSIS OF BREAST
}

\section{Dr. Shantha Mohanasundaram, Dr. Hemanathan G, Department of Pathology Dr. Deepa N, Department of General Surgery}

Shri Sathya Sai Medical College \& Research Institute, Sri Balaii Vidyapeeth, Nellikuppam, Kancheepuram Dist., Tamil Nadu - 603 108, India.

\begin{abstract}
Tuberculosis of breast is rare in the west.It is rare even in developing countries where the incidence of Extra Pulmonary Tuberculosis is high. Kancheepuram District in Tamilnadu is known for its endemicity in Tuberculosis. Tuberculosis of breast occurring in young female which is a rare site for Extra Pulmonary Tuberculosis is presented here.
\end{abstract}

Key Words: Breast tuberculosis, Epitheloid granuloma, Langhan's giant cells

\section{Introduction}

Tuberculosis is broadly classified into pulmonary and extra pulmonary tuberculosis based on the site of occurrence. Extra pulmonary tuberculosis is seen in brain,bones,jo ints,kidneys,testes,ovary, spleen, thyroid and breast. The occurrence of tuberculosis in breast is rare ${ }^{1}$ among the extra pulmonary lesions. It is also rare even in developing countries like India, where the incidence is high ${ }^{2}$.This could be due to the hostile environment of the breast, which resists the proliferation of Tubercle bacilli-Mycobacterium tuberculosis. Tuberculosis breast was first reported in the west in 1829 by Sir Astley Cooper ${ }^{3}$.In India the first case was reported by Choudary in $1957^{4}$. The incidence in India is between 0.64 to $3.59 \%$, 6 . Tuberculosis of breast in western countries is less than $0.1 \%$ of breast lesions. Tuberculosis of the breast presenting as a lump is difficult in differentiating it from carcinoma breast ${ }^{7}$.

\section{Case History}

A 28year old female came to the surgical outpatient Department of Shri Sathya Sai Medical College and Research Institute, with complaints of swelling in the left breast of one month duration. She had no history of pain or fever. Her last child birth was two years ago on examination a lump $6 \times 3 \mathrm{cms}$ was made out in the upper outer quadrant. No ulceration over the swelling. No nipple discharge. The central axillary lymph nodes was enlarged .The following investigation were done.

Haemoglobin $-10.5 \mathrm{~g} / \mathrm{dl}$

ESR-12 minutes 1 hour

Xray chest- with in normal limits

FNAC breast and Lymphnode -Nonspecfic inflammatory lesion.

The clinical diagnosis was considered as 1. Carcinoma of breast.2. Pyogenic abscess.

Later the patient underwent lumpectomy. Lump was sent for histopathological examination.

\section{Pathological Findings}

Gross examination of specimen showed skin covered yellowish soft tissue mass $10 \times 8.5 \times 5 \mathrm{~cm}$.

Cut surface of the mass was yellowish $6 \times 3 \times 3 \mathrm{~cm}$, and firm in consistency [Fig 1]. 


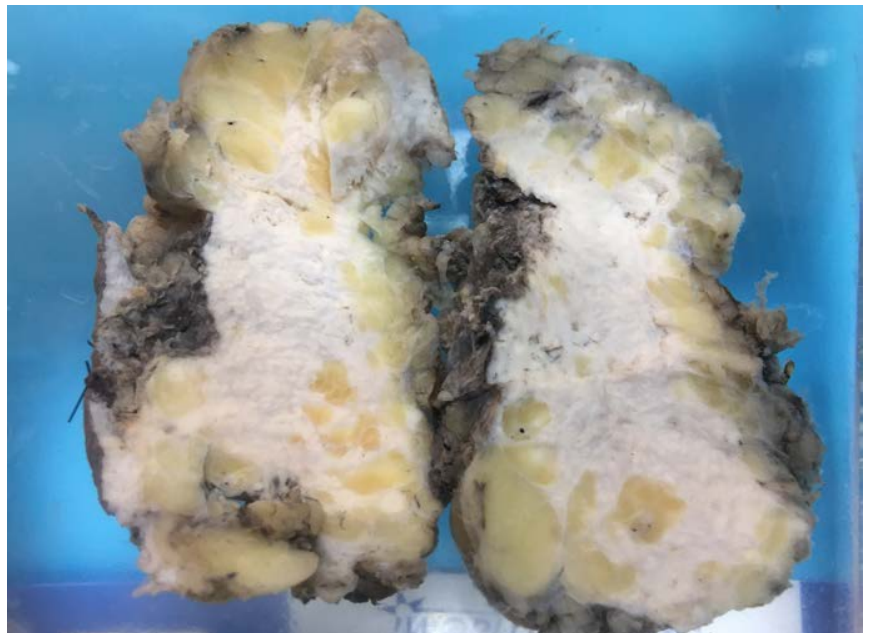

Fig.1: Cut surface of the breast showing fat (yellow) and whitish area - TB lesion

Microscopic examination showed breast tissue with multiple epitheloid granuloma with central caseous necrosis surrounded by Langhans giant cells and lymphocytes [Fig 2a \& $2 \mathrm{~b}$ ]. Based on these findings a diagnosis of Tuberculosis breast was made.

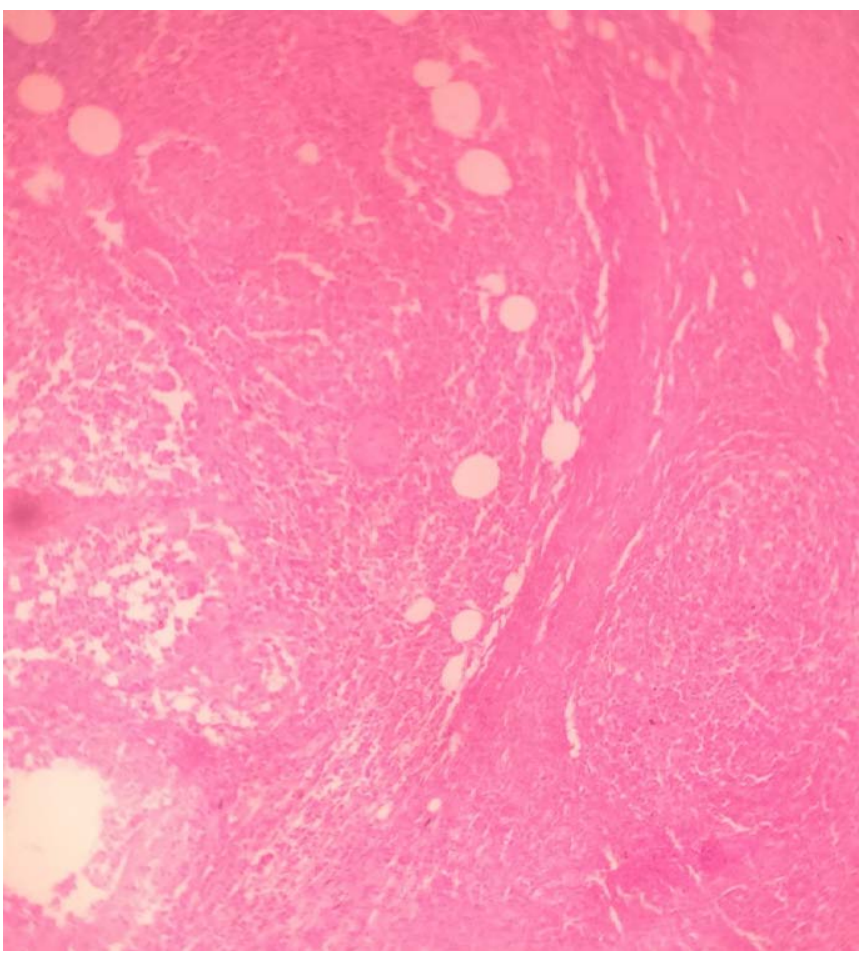

Fig.2 a) Multiple epitheloid granuloma in breast tissue (H and E X10)

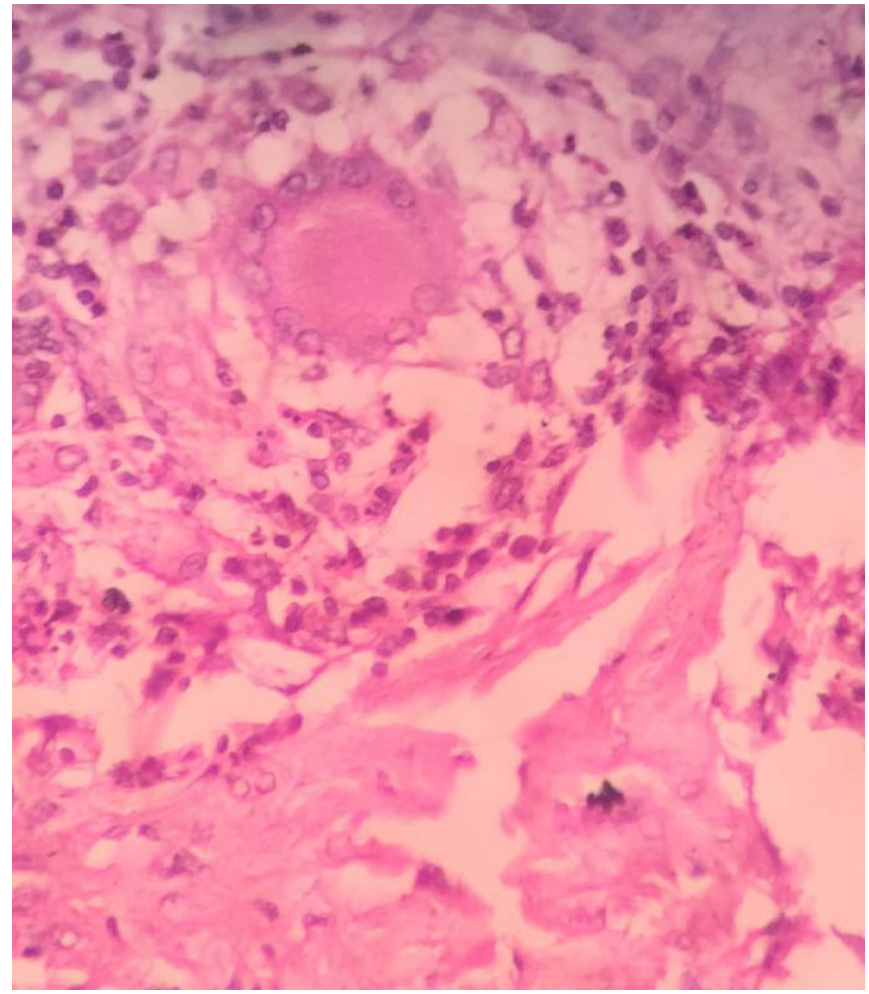

Fig 2 b) Epitheloid granuloma with Langhan's Giant cells and surrounding lymphocytes (H and E X 40

The patient was put on anti tuberculosis drugs.

\section{Discussion}

Tuberculosis is rare in breast tissue. If at all seen, it is observed in young lactating women. It is uncommon in puerperal girls and older women. It is rare in males. The more susceptible ones are pregnant and lactating women. Lactating breast is easily affected due to increase vascularity and dilated ducts with predisposition to trauma ${ }^{8}$, which aid in the spread of infection. The routes of spread are blood, lymphatics and extension from adjacent tissue. Now it is accepted the majority of TB breast is secondary . The primary focus could be elsewhere in the body ${ }^{8}$. The lesion is usually seen in the upper outer quadrant ${ }^{9}$ due to spread from axillary node lesion. In our case all the above findings were present.

However at times the lump may be hard, and fixed to the underlying skin and muscle simulating malignancy. Sometimesit can also discharge pus through sinuses simulating pyogenic abscess. 


\section{TB Breast is classified as}

\section{Nodular Tuberculosis mastitis \\ Disseminated Tuberculosis}

Breast abscess.

\section{Nodular Tuberculosis Mastitis}

Common variety,well circumscribed and painless.It is difficult in the later stages to differentiate from breast carcinoma $^{10}$.

\section{Disseminated Tuberculosis}

It is a rare type. Multiple foci are seen in the breast.Lesion is painfull, ulceration is seen in the skin.Multiple sinuses are seen in the skin. The draining nodes are enlarged and matted.

\section{Breast Abscess}

Sometimes TB breast present as breast abscess with pus formation.

\section{Conclusion}

Tuberculosis of Breast is rare.It is uncommon even in places where the incidence of Tuberculosis is high. Tuberculosis of breast is often misdiagnosed as carcinoma of breast.It can be treated with anti Tuberculosis drugs. Residual lump can be removed by surgery.If correct diagnosis is made mutilating surgery like radical mastectomy done for breast carcinoma can be avoided.

\section{REFERENCES}

1. Kakkar S, Kapila K, Singh MK, Verma K. Tuberculosis of the breast: A cytomorphologic study. ActaCytol. 2000;44:292-6.

2. Rangabashyam N, Gnanaprakasan D, Krishnaraj B, Manohar V, Vijayalakshmi SR. Spectrum of benign breast lesions in Madras. J R CollSurgEdinb 1983;28:369-73.

3. Cooper A. Illustration of the diseases of the breast. Part I.London: Longman, Rees, Orme, Brown and Green; 1829. p. 73.

4. Chaudhary M. Tuberculosis of the breast. Br J Dis Chest 1957; 23 : 195-9.

5. Dharkar RS, Kanhere MH, Vaishya ND, Baisarya AK. Tuberculosis of the breast. J Indian Med Assoc 1968; $50: 207-9$

6. Mukerjee P, George M, Maheshwari HB, Rao CP. Tuberculosis of the breast. J Indian Med Assoc. 1974;62:410-2.

7. Shinde SR, Chandawarkar RY, Deshmukh SP. Tuberculosis of the breast masquerading as carcinoma: A study of 100 patients. World $\mathrm{J}$ Surg. 1995;19:379-81.

8. Banerjee SN, Ananthakrishnan N, Mehta RB, Prakash S. Tuberculosis mastitis: A continuing problem. World J surg 1987; 11:105-9.

9. Shukla HS, Kumar S. Benign breast disorders in nonwestern populations: Part II - Benign breast disorders in India. World J Surg. 1989;13:746-9.

10. Graunsman RI, Goldman ML. Tuberculosis of the breast-report of nine cases including two cases of co-existing carcinoma and tuberculosis. Am J Surg. 1945;67:48. 